\title{
Pomiar gamma-gamma oraz komputerowa tomografia rentgenowska na rdzeniach wiertniczych skał osadowych
}

\begin{abstract}
Metody badawcze wykorzystujące absorpcję promieniowania elektromagnetycznego zostały zastosowane do ciągłych pomiarów gęstości rdzeni wiertniczych pobranych ze skał różniących się litologią oraz właściwościami petrofizycznymi. Pomiary gamma-gamma oraz tomografia komputerowa pozwalają na rejestrację profilu zmian gęstości z dużą rozdzielczością, bez ingerencji w analizowany materiał - metody nieinwazyjne. Zastosowanie badań całych rdzeni pozwoli na wprowadzenie oszczędności w budżetach firm poszukiwawczych, które często ograniczają rdzeniowanie, a przez to pomiary laboratoryjne do minimum. W przypadku występowania w badanych rdzeniach cienkich wkładek skał o odmiennej litologii, szczelin oraz żyłek kalcytowych - analizy wykonane na całym dostępnym materiale znacznie zwiększą możliwości interpretacyjne geofizyki otworowej. Do przeprowadzenia badań wykorzystano spektrometr gamma z aplikacją do pomiarów gęstości elektronowej (gamma logger core density - GLCD) oraz medyczny tomograf komputerowy z aplikacją konwertującą pliki graficzne na ciągły profil zmian gęstości wyrażonej w jednostkach Hounsfielda (computed tomography core density - CTCD). W pracy przedstawiono metodykę rejestracji parametrów oraz interpretację otrzymanych wyników.
\end{abstract}

Słowa kluczowe: promieniowanie gamma, gęstość objętościowa, tomografia komputerowa, analiza rdzeni wiertniczych, skały osadowe.

\section{Gamma-gamma measurements and X-ray computed tomography applied to sedimentary rock cores}

Methods based on electromagnetic radiation absorption were applied to continuous density measurements, on rock cores of diverse lithology and petrophysical properties. Non-destructive techniques such as gamma-gamma and computed tomography measurements, allow for high resolution density core logging. Application of the proposed methods to whole core studies, helps with saving budget of companies, that reduces coring and laboratory measurements to minimum. In case of the occurrence of thin layers with different lithology, fractures or calcium veins, analysis performed on the entire available material will significantly increase the capabilities of well logging interpretation. To perform the tests, gamma spectrometer with bulk density application (gamma logger core density - GLCD) and medical tomography with an application which converts image files to continuous profile of density changes expressed in Hounsfield units (computed tomography core density - CTCD) were used. In this study the measurement method and the results interpretation technique were presented.

Key words: gamma radiation, bulk density, computed tomography, core analyze, sedimentary rocks.

\section{Wstęp}

Właściwości skał zbiornikowych oraz uszczelniających mają ogromne znaczenie dla przemysłu naftowego. Ich oceną zajmują się szeroko rozwinięte zespoły pomiarowo-interpretacyjne petrofizyków i specjalistów od geofizyki otworowej. Przedmiotem prac wymienionych specjalistycznych grup są pomiary otworowe, wykonywane zaraz po zakończeniu procesu wiercenia, oraz badania laboratoryjne, które dają informacje uzupełniające, wykorzystywane w kompleksowej interpretacji geofizyki otworowej - szczególnie badania mineralogiczne i geochemiczne. Rozwój nowoczesnych metod pomiarowych powoduje zwiększenie wiedzy na temat fizycznych parametrów skał. Jednak badania laboratoryjne odnoszą się zazwyczaj do pomiarów okruchów skalnych lub calowych rdzeni, co powoduje uzyskanie 
punktowej informacji w skali innej niż ciągłe wyniki geofizyki otworowej.

Celem pracy jest przedstawienie możliwości wykorzystania całego rdzenia wiertniczego do przeprowadzenia pomiarów gęstości z wykorzystaniem absorpcji promieniowania elektromagnetycznego (naturalnego promieniowania gamma oraz sztucznego X). Pod względem właściwości fizycznych promieniowanie gamma i rentgenowskie są do siebie podobne. Główna różnica polega na sposobie ich powstawania [8]. Wyniki wykonanych analiz zostały skorelowane z wynikami badań laboratoryjnych przeprowadzonych przy użyciu aparatur GeoPyc i Accupyc (Micromeritics Instrument Corp.) oraz profilowania otworowego (krzywa RHOB) w celu ich integracji. Badania wykonano na skałach osadowych (piaskowcach, dolomitach, anhydrytach). Wyniki badań mogą wnieść do kompleksowej interpretacji modelowanego złoża węglowodorów cenne, a zarazem dokładne informacje o dużej rozdzielczości pionowej. Otworowe profilowania gęstościowe gamma-gamma wykorzystuje się przede wszystkim do określenia gęstości objętościowej skał, litologii analizowanego profilu oraz dopasowania głębokościowego. Tomografia komputerowa pozwala na utworzenie dokumentacji fotograficznej rdzenia 3D/2D wraz z warstwami i laminacjami, które nie są możliwe do zarejestrowania przez inne metody badawcze. Porównanie takiego obrazu z wynikiem elektrycznego obrazowania ścianki otworu pozwala dopasować głębokościowo rdzeń oraz znacznie rozszerzyć wiedzę na temat systemu spękań w analizowanych warstwach. Za pomocą przetwarzania obrazu otrzymuje się profil zmian współczynników osłabienia promieniowania elektromagnetycznego wyrażonego w jednostkach Hounsfielda (HU - Hounsfield units). Wynik przetwarzania jest bezpośrednio powiązany z gęstością objętościową, w literaturze obcej określa się go jako radiodensity.

\section{Metody}

Przedstawione w pracy metody pomiarowe należą do grupy metod nieinwazyjnych. Rdzeń po takich badaniach pozostaje w stanie nienaruszonym, co pozwala na późniejsze uzyskanie wielu danych z tego samego materiału. Pomiary na rdzeniu wiertniczym najlepiej jest wykonać zaraz po wydobyciu go z otworu, przed pobraniem prób do badań laboratoryjnych. Pozwala to na osiągnięcie najlepszych wyników z całości dostępnego materiału oraz może być pomocne przy typowaniu prób do dalszych, dokładniejszych badań [6]. Do realizacji niniejszej pracy wykorzystano rdzenie archiwalne, które często sprawiają trudności, ponieważ braki w materiale oraz zły stan fizyczny nie pozwalają na osiągnięcie ciągłych profili wynikowych.

\section{Komputerowa tomografia rentgenowska}

Pomiary tomograficzne (CT) wykonywane są nowoczesnym tomografem medycznym - Philips Ingenuity CT, w którym zastosowano technikę DAS (Data Acquisition and Sampling), pozwalającą uzyskać cienkie, 128-warstwowe rekonstrukcje o wysokiej rozdzielczości, sięgającej do $0,4 \mathrm{~mm}$. Budowa nowoczesnego aparatu oraz jego system chłodzący pozwalają na ciągłe pomiary nawet długich rdzeni wiertniczych. Najważniejszą częścią aparatury jest gantry - element, w którym znajduje się lampa rentgenowska wraz z systemem detektorów i przetwornicą wysokiego napięcia, umożliwiający zasilanie, oraz układ elektroniczny odpowiedzialny za obrót jednostki pomiarowej wokół osi rdzenia. Skanowane obrazy poddawane są rekonstrukcji z użyciem najnowszego oprogramowania dołączonego do aparatury pomiarowej. Pozwala ono na przetwarzanie do ponad 30 obrazów na sekundę [15].
Przed przystąpieniem do skanowania rdzenie muszą zostać zorientowane w skrzynkach oraz zabezpieczone przed ponowną rotacją. Czynność ta zapewnia rzeczywiste odwzorowanie upadu warstw w całym profilu rdzenia. Decydującą rolę w uzyskaniu poprawnych wyników pełni opracowywana od ponad dwóch lat w INiG - PIB metodyka przetwarzania zarejestrowanych obrazów. Zgodnie z tą metodyką obraz można przedstawić w przestrzeni $3 \mathrm{D}$, gdzie widoczna jest wewnętrzna struktura rdzenia, oraz w postaci $2 \mathrm{D}-\mathrm{w}$ formie rozwinięcia walca. Wtedy obraz ten może być porównywany z zapisem sondy XRMI. Można także przedstawić wynik $1 \mathrm{D} w$ postaci wysokorozdzielczego zapisu numerycznego CTCD. Wpływ drewnianych skrzynek, otulin zabezpieczających rdzenie oraz otaczającego powietrza jest eliminowany podczas przetwarzania danych. Program komputerowy wymaga wyznaczenia środka walca, promienia oraz kąta, na którym ma się rozpocząć rozwinięcie. Do wygenerowanych obrazów dobierane są odpowiednie palety barw, aby uwidocznić słabo dostrzegalne przewarstwienia lub spękania. Otrzymany profil tomograficzny jest składany w oprogramowaniu umożliwiającym edycję plików graficznych.

Absorpcja promieniowania elektromagnetycznego w materiale skalnym zależy od składu chemicznego skały [7]. Każdy składnik, minerał lub pierwiastek posiada inną wartość absorpcji. Do utworzenia profilu CTCD wymagany jest program przetwarzający wartości z obrazu tomograficznego na uśredniony wynik w punkcie pomiarowym. W tym celu dr hab. Zbisław Tabor napisał program komputerowy, który umożliwia szybką i łatwą konwersję obrazu na zapis numeryczny. Parametry, które należy zadać, to gęstość 
próbkowania (z jakiego obszaru ma być uśredniany każdy wynik w punkcie pomiarowym) oraz wybrany obszar obrazu, w którym znajduje się rdzeń.

Największą zaletą nieinwazyjnej rentgenowskiej tomografii komputerowej jest wyjątkowo wysoka rozdzielczość oraz idąca za nią dokładna informacja o gęstości objętościowej i strukturze rdzenia [2].

W najnowszych pracach naukowych pokazano przykłady badania intruzji piaskowcowych na podstawie przestrzennych obrazów rdzeni [9]. Tomografia często jest wykorzystywana w paleontologii do lokalizowania szczątków skamieniałości przed przystąpieniem do ich oczyszczania z ciasta skalnego [1].

\section{Spektrometria gamma zaktywnym źródlem do pomiaru gęstości}

Standardowe metody laboratoryjne wyznaczania gęstości skał oparte są na pomiarach masy próbki oraz jej objętości [12]. W przypadku materiałów porowatych, jakimi są skały, gęstość może odnosić się do szkieletu skalnego - gęstość właściwa oraz do całej próbki wraz z porami - gęstość objętościowa. Podstawowe metody laboratoryjne wyznaczania gęstości to metoda piknometru helowego oraz metoda Archimedesa [4].

Alternatywną metodą jest pomiar gęstości elektronowej przy wykorzystaniu źródeł aktywnych, emitujących promieniowanie gamma o znanej energii [11], oraz zestawu wzorców kalibracyjnych. Zasada wykonywania pomiarów gęstości elektronowej z użyciem źródła ${ }^{137} \mathrm{Cs}$ o energii $0,662 \mathrm{MeV}$ polega na wykorzystaniu detekcji intensywności promieniowania gamma, które przechodząc przez rdzeń wiertniczy, zanika ekspotencjalnie z powodu osłabienia poszczególnych fotonów oddziałujących z materią [11]. Mierzona intensywność promieniowania gamma jest skutkiem efektu Comptona oraz zjawiska fotoelektrycznego. Efekt tworzenia par (elektron-pozyton) jest pomijany, ponieważ sygnał od tego zjawiska powstaje na wysokoenergetycznej części widma, w dużej odległości od piku o charakterystycznej energii dla cezu. Absorpcja badanego materiału zależy od jego składu chemicznego oraz gęstości. Rdzenie wiertnicze o większej gęstości pozwalają na zajście większej ilości interakcji emitowanych elektronów w swojej objętości, co przekłada się na zmniejszenie liczby fotonów docierających do objętości czynnej detektora [12]. Pomiary gęstościowe gamma-gamma są często wykorzystywane do oznaczania gęstości cieczy płynących w rurach $[5,10]$, pozwalają na ciągły monitoring płynów.

Do pomiarów gęstości GLCD wykorzystano spektrometr gamma logger (BGO), przystosowany do rejestracji widma naturalnego promieniowania gamma rdzeni wiertni- czych. Spektrometr jest przeznaczony do pomiarów metrowych odcinków rdzeni i posiada zautomatyzowany system przesuwczy. Dwucalowy kryształ $\mathrm{BGO}\left(\mathrm{Bi}_{4} \mathrm{Ge}_{3} \mathrm{O}_{12}\right.$ - germanian bizmutu) cechuje się wysoką wydajnością oraz czułością na rejestrację kwantów gamma o zróżnicowanej energii. Aby wykorzystać spektrometr do pomiaru gęstości, należy zastosować dodatkowe źródło w postaci izotopu ${ }^{137} \mathrm{Cs}$ oraz zestaw wzorców kalibracyjnych. Do oszacowania gęstości rdzeni wykorzystuje się sumę zliczeń detektora (CPM - counts per minute) otrzymaną dla dwóch wzorców gęstościowych, odpowiadających układowi geometrycznemu rdzenia. W tablicy 1 podano rzeczywistą gęstość wzorców (AL - posiada domieszki miedzi).

Tablica 1. Gęstościowe wzorce kalibracyjne

\begin{tabular}{|l|c|c|}
\hline \multicolumn{1}{|c|}{ Nazwa wzorca } & $\begin{array}{c}\text { Średnica } \\
{[\mathrm{cm}]}\end{array}$ & $\begin{array}{c}\text { Gęstość } \\
{\left[\mathrm{g} / \mathrm{cm}^{3}\right]}\end{array}$ \\
\hline Wzorzec aluminiowy (AL) & 6,4 & 2,82 \\
\hline Wzorzec poliwęglanowy (PW) & 6,4 & 1,19 \\
\hline Wzorzec aluminiowy (AL10) & 10,0 & 2,71 \\
\hline Wzorzec poliwęglanowy (PW10) & 10,0 & 1,20 \\
\hline
\end{tabular}

Układ pomiarowy został przedstawiony na rysunku 1 . Możliwe jest automatyczne przemieszczanie detektora nad rdzeniem wraz z równoległym przemieszczaniem źródła. To rozwiązanie pozwala na ograniczenie przebywania personelu w pobliżu stosowanego źródła cezowego ${ }^{137} \mathrm{Cs}$, o aktywności $370 \mathrm{kBq}(10 \mathrm{mCi})$.

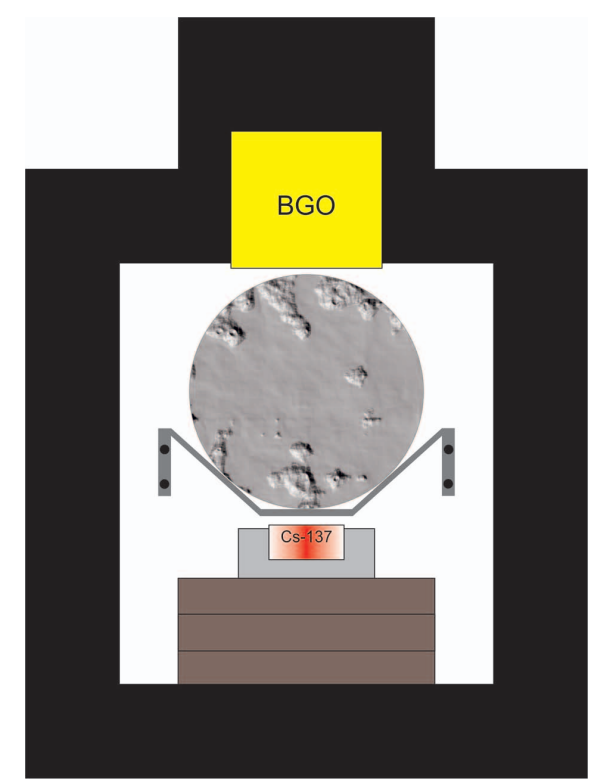

Rys. 1. Grafika przedstawiająca układ pomiarowy aparatury stosowanej do rejestracji gęstości elektronowej $\mathrm{z}$ wykorzystaniem detektora $\mathrm{BGO}$ oraz aktywnego źródła ${ }^{137} \mathrm{Cs}$, umieszczonego w ołowianym tunelu o długości $40 \mathrm{~cm}$ i grubości ścian $5 \mathrm{~cm}$ 


\section{Wyniki badań i dyskusja}

Wstępne badania gęstości GLCD zostały przeprowadzone na wzorcach kalibracyjnych, w celu oceny powtarzalności wyników oraz sprawdzenia, czy materiał z którego są wykonane wzorce, jest izotropowy. Analizy na rdzeniach zostały przeprowadzone na materiale skalnym z czterech otworów wiertniczych: BJK; JJ-1; P-4; Pt-1. Materiał użyty do badań był zróżnicowany pod względem litologii, rdzenie miały różne średnice i charakteryzowały się zróżnicowanym stanem fizycznym. Różnica w rozdzielczości metod GLCD i CTCD pozwoliła na sprawdzenie, jak zmienność litologiczna spowodowana obecnością cienkich warstw wpływa na uśredniane wyniki. Zarówno obrazy z tomografu medycznego, jak i gęstość CTCD mierzone są z krokiem 0,4 mm, krzywa wynikowa uśredniana jest do $1,2 \mathrm{~cm}$ lub 1,6 cm, natomiast gam- ma logger, w przypadku pomiarów gamma-gamma i wykorzystania źródła ukierunkowanego, pozwala na pomiar o rozdzielczości poniżej $5 \mathrm{~cm}$ (pomiary standardowo wykonuje się z krokiem $10 \mathrm{~cm}$ lub $5 \mathrm{~cm}$ ).

Badania wzorców gęstościowych o średnicy $6,4 \mathrm{~cm}$ i długości $50 \mathrm{~cm}$ zostały przeprowadzone z krokiem pomiarowym $1 \mathrm{~cm}$ na długości $35 \mathrm{~cm}$. Czas ekspozycji dla każdego punktu został ustawiony na 2 minuty. Kalibracja aparatury była przeprowadzana przed każdą serią pomiarową. Wyniki przedstawiono na rysunku 2.

\section{Otwór BJK}

Analizy korelacyjne CTCD/GLCD przeprowadzono na serii pomiarów wykonanych na dwóch metrowych odcinkach

\begin{tabular}{|c|c|c|c|c|}
\hline \multicolumn{4}{|c|}{ Poliwęglan } & 1,0 \\
\hline $\mathrm{nr}$ & ID & CPM & Dens $\left[\mathrm{g} / \mathrm{cm}^{3}\right]$ & $\longleftarrow$ \\
\hline 1 & 41115 & 116520,9 & 1,203 & 柘 \\
\hline 2 & 41116 & 116827,9 & 1,191 & 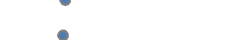 \\
\hline 3 & 41117 & 116672,4 & 1,197 & 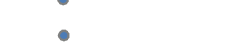 \\
\hline 4 & 41118 & 116313,9 & 1,211 & 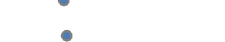 \\
\hline 5 & 41119 & 117100,1 & 1,181 & $\longrightarrow$ \\
\hline 6 & 41120 & 117000,7 & 1,185 & 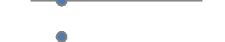 \\
\hline 7 & 41121 & 116252,8 & 1,213 & 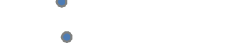 \\
\hline 8 & 41122 & 117232,3 & 1,176 & 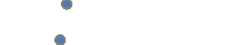 \\
\hline 9 & 41123 & 116889,2 & 1,189 & $\bullet$ \\
\hline 10 & 41125 & 117325,5 & 1,172 & 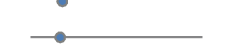 \\
\hline 11 & 41126 & 116748,4 & 1,194 & 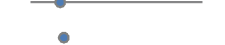 \\
\hline 12 & 41127 & 116771,4 & 1,193 & $\bullet$ \\
\hline 13 & 41128 & 117291,8 & 1,173 & $\bullet$ \\
\hline 14 & 41130 & 117149,7 & 1,179 & - \\
\hline 15 & 41131 & 116464,6 & 1,205 & $\rightarrow$ \\
\hline 16 & 41132 & 116518,8 & 1,203 & - \\
\hline 17 & 41133 & 117274,7 & 1,174 & $\bullet$ \\
\hline 18 & 41134 & 116993,4 & 1,185 & - \\
\hline 19 & 41135 & 117548,6 & 1,163 & $\bullet$ \\
\hline 20 & 41136 & 117146,5 & 1,179 & $\rightarrow$ \\
\hline 21 & 41137 & 117095,3 & 1,181 & $\bullet$ \\
\hline 22 & 41138 & 116796,3 & 1,192 & $\bullet$ \\
\hline 23 & 41139 & 117118,3 & 1,180 & $\bullet$ \\
\hline 24 & 41140 & 116460,8 & 1,205 & - \\
\hline 25 & 41141 & 116840,8 & 1,191 & $\longrightarrow$ \\
\hline 26 & 41142 & 116582,6 & 1,201 & $\bullet$ \\
\hline 27 & 41143 & 117228,9 & 1,176 & $\bullet$ \\
\hline 28 & 41144 & 117290,8 & 1,173 & $\bullet$ \\
\hline 29 & 41145 & 116966,2 & 1,186 & - \\
\hline 30 & 41146 & 117213,6 & 1,176 & $\bullet$ \\
\hline 31 & 41147 & 116960,2 & 1,186 & - \\
\hline 32 & 41148 & 117118,5 & 1,180 & - \\
\hline 33 & 41149 & 116329,4 & 1,210 & - \\
\hline 34 & 41150 & 116618,8 & 1,199 & - \\
\hline 35 & 41152 & 116792,2 & 1,193 & $\longrightarrow$ \\
\hline
\end{tabular}

Odchylenie standardowe Błąd z odchylenia st.

\begin{tabular}{|c|c|c|c|}
\hline \multicolumn{4}{|c|}{ Aluminium } \\
\hline $\mathrm{nr}$ & ID & CPM & Dens $\left[\mathrm{g} / \mathrm{cm}^{3}\right]$ \\
\hline 1 & 41077 & 74783,2 & 2,814 \\
\hline 2 & 41078 & 74619,4 & 2,821 \\
\hline 3 & 41079 & 74598,3 & 2,822 \\
\hline 4 & 41080 & 75089,1 & 2,803 \\
\hline 5 & 41081 & 74064,1 & 2,842 \\
\hline 6 & 41082 & 75079,3 & 2,803 \\
\hline 7 & 41083 & 74449,5 & 2,827 \\
\hline 8 & 41084 & 74972,3 & 2,807 \\
\hline 9 & 41085 & 75235,9 & 2,797 \\
\hline 10 & 41086 & 75133,5 & 2,801 \\
\hline 11 & 41087 & 74816,2 & 2,813 \\
\hline 12 & 41088 & 74735,4 & 2,816 \\
\hline 13 & 41089 & 74575,4 & 2,822 \\
\hline 14 & 41090 & 75000,1 & 2,806 \\
\hline 15 & 41091 & 74918,1 & 2,809 \\
\hline 16 & 41092 & 74268,7 & 2,834 \\
\hline 17 & 41093 & 74113,3 & 2,840 \\
\hline 18 & 41094 & 74276,1 & 2,834 \\
\hline 19 & 41095 & 74775,2 & 2,815 \\
\hline 20 & 41096 & 74469,7 & 2,827 \\
\hline 21 & 41097 & 74855,8 & 2,812 \\
\hline 22 & 41098 & 74391,9 & 2,830 \\
\hline 23 & 41099 & 73927,5 & 2,847 \\
\hline 24 & 41100 & 74879,7 & 2,811 \\
\hline 25 & 41101 & 74438,9 & 2,828 \\
\hline 26 & 41102 & 74997,5 & 2,806 \\
\hline 27 & 41103 & 74369,6 & 2,830 \\
\hline 28 & 41104 & 74410,3 & 2,829 \\
\hline 29 & 41105 & 74768,8 & 2,815 \\
\hline 30 & 41106 & 74648,2 & 2,820 \\
\hline 31 & 41107 & 74914,5 & 2,809 \\
\hline 32 & 41108 & 74727,7 & 2,817 \\
\hline 33 & 41109 & 74026,0 & 2,844 \\
\hline 34 & 41110 & 73739,8 & 2,855 \\
\hline 35 & 41111 & 73846,1 & 2,851 \\
\hline
\end{tabular}

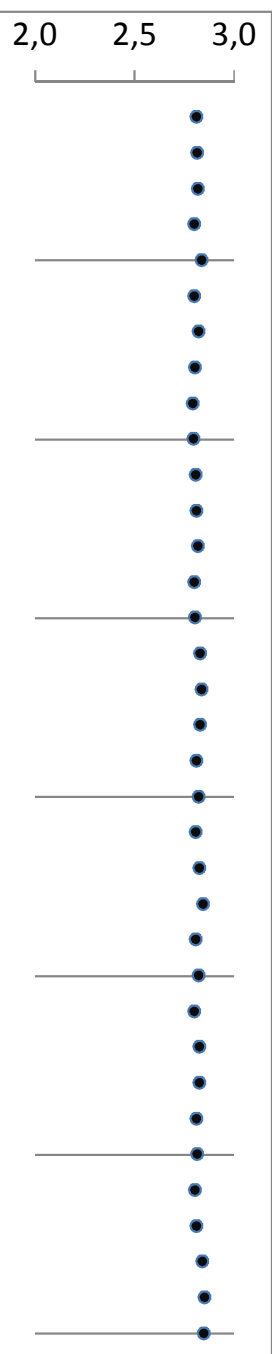

\begin{tabular}{|l|c|}
\hline Odchylenie standardowe & $\mathbf{0 , 0 1 5}$ \\
\hline Błąd z odchylenia st. & $0,25 \%$ \\
\hline
\end{tabular}

Rys. 2. Zestawienie wyników z pomiarów GLCD wzorców kalibracyjnych przeznaczonych do badań gęstości objętościowej; $\mathrm{nr}$ - punkt pomiarowy; ID - numer widma; CPM - liczba zliczeń detektora; Dens - gęstość objętościowa.

Pod tabelą przedstawiono odchylenie standardowe oraz oszacowany błąd pomiarowy 

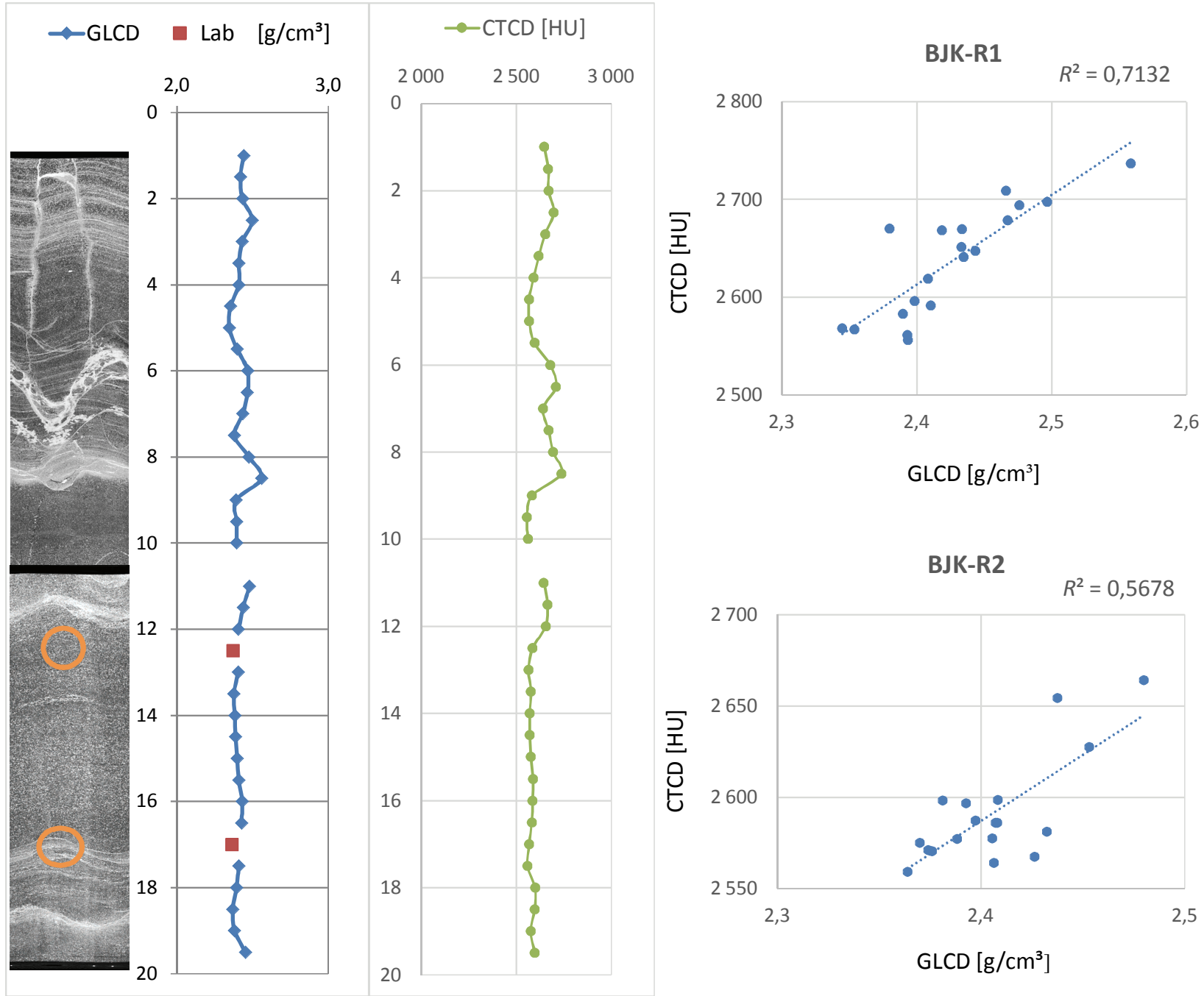

Rys. 3. Zestawienie oraz korelacja wyników z pomiarów aparaturą gamma logger (GLCD) oraz tomografem medycznym (CTCD); Lab - pomiary gęstości objętościowej w laboratorium. BJK-R1 przedstawiono w górnej części wykresu, BJK-R2 w części dolnej. Pomarańczowe koła oznaczają punkty, w których pobrano próbki do badań laboratoryjnych

rdzenia BJK-R1 oraz BJK-R2. Badane rdzenie to piaskowce, znacznie różniące się strukturą. Krok pomiarowy w przypadku GLCD został ustawiony na $5 \mathrm{~cm}$, czas pomiarowy na 2 minuty. Pomiary CT wykonano przed poborem prób do badań laboratoryjnych, stąd obrazy oraz profil CTCD są przebadane całościowo. Wynik CTCD został uśredniony w celu dopasowania punktów pomiarowych co $5 \mathrm{~cm}$. Na dwóch punktach zaznaczonych na odcinku BJK-R2 wykonano badania laboratoryjne (rysunek 3).

Dane otrzymane z pomiarów dwoma różnymi aparatami wykazały się zadowalającym współczynnikiem determinacji $R^{2}$ (dla BJK-R1 $R^{2}=0,71$; dla BJK-R2 $R^{2}=0,57$ ). Średnia gęstość objętościowa dla odcinków R1 i R2 wynosiła odpowiednio $2,43 \mathrm{~g} / \mathrm{cm}^{3}$ i $2,41 \mathrm{~g} / \mathrm{cm}^{3}$, natomiast średnia gęstość wyrażona w jednostkach Hounsfielda wynosiła $2638 \mathrm{HU}$ i 2590 HU. Na wzrost gęstości w przypadku R1 wpłynęła mocno rozbudowana struktura żyłek węglanowych wypełniających spękania utworów piaskowcowych.

\section{Otwór JJ-1}

Na dwóch metrowych odcinkach rdzenia wiertniczego z otworu JJ-1 wykonano serie badań gamma-gamma, po 5 dla każdego punktu, w celu oszacowania błędu pomiarowego oraz sprawdzenia powtarzalności metody (rysunek 4). Czas pomiarowy ustawiono na 2 minuty, krok na $10 \mathrm{~cm}$. Wykresy przedstawiają punkty od 1 do 9 dla R2 oraz od 1 do 8 dla R3. Każda seria pomiarowa 5 punktów oznacza powtórzenie pomiaru dokładnie w tym samym miejscu - na wykresie punkty przedstawione są $\mathrm{w}$ odstępach dla zobrazowania zróżnicowania wartości. Na każdym wykresie załączone zostało zdjęcie badanego rdzenia, w celu wythumaczenia anomalii, oraz wykresy wartości błędu wyrażonego w skali procentowej. Na wykresach przedstawiono: profil gęstości objętościowej zbudowany na podstawie uśrednionych wyników z pięciu punktów GLCD, krzywą „Interp”, z wyinterpolowanymi punktami, które wychodzą poza skalę gęstości, oraz punkty z badań laboratoryjnych „Lab” - gęstość objętościowa. 

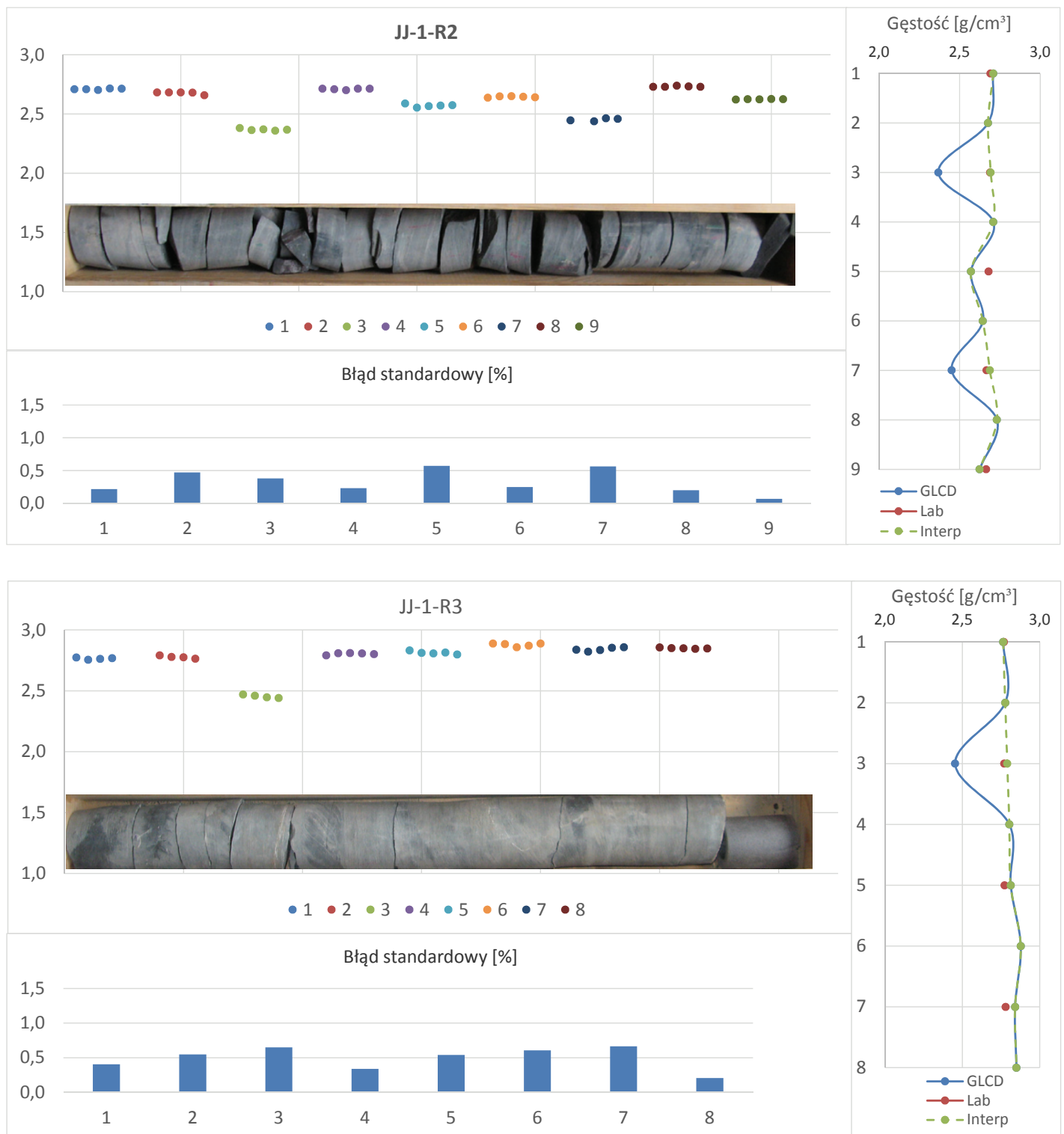

Rys. 4. Szacowanie standardowego błędu pomiarowego metody na podstawie serii badań dla rdzeni R-2 i R-3 z otworu JJ-1

Badania przeprowadzono na dostępnym materiale rdzeniowym pochodzącym z utworów karbońskich (piaskowce, mułowce). Rdzenie były dość mocno spękane, ułożenie ich w rynnie pomiarowej pozwoliło ograniczyć wpływ szczelin do minimum. Część wyników została odrzucona na etapie przetwarzania z powodu zarejestrowania zniekształconego widma, stąd dla niektórych punktów są dostępne cztery analizy. Wyniki cechują się dużą precyzją, oszacowane błędy pomiarowe w przypadku większości punktów nie przekraczają jednego procenta. Dla R-2 punkty 3 i 7 oraz dla R3 punkt 3 cechują się sztucznie zaniżonymi gęstościami objętościowymi. Spowodowane jest to pomiarem wykonanym nad skruszonym materiałem lub szczeliną.

Rdzeń R-3, który został pobrany z większej głębokości, ma większą gęstość objętościową, co spowodowane jest wpływem kompakcji oraz udziałem kalcytu, oznaczonego na podstawie analiz chemicznych. Rdzenie z otworu JJ-1 cechowa- ły się podwyższoną promieniotwórczością naturalną, co wykazały wyniki otrzymane na podstawie badań przeprowadzonych spektrometrem gamma logger. Materiał o podwyższonej radioaktywności z otworu został wykorzystany do sprawdzenia wpływu zliczeń detektora w oknach potasowym, uranowym oraz torowym [14]. Pomiary miały na celu określenie wpływu naturalnej promieniotwórczości rdzeni (zawyżanie zliczeń detektora przez K, U, Th) na otrzymane gęstości objętościowe. Analiza gęstości objętościowej z zapisu widmowego (rysunek 5) na podstawie pomiarów GLCD polegała na eksporcie widm spektrometrycznych do plików zewnętrznych oraz wykorzystaniu do szacowania gęstości objętościowej zliczeń w oknie występowania piku pochodzącego od ${ }^{137} \mathrm{Cs}$. W przypadku skał o niskiej promieniotwórczości ta operacja może zostać pominięta z powodu niewielkiego wpływu zliczeń pochodzących od pierwiastków radioaktywnych w stosunku do zliczeń dla źródła cezowego. 


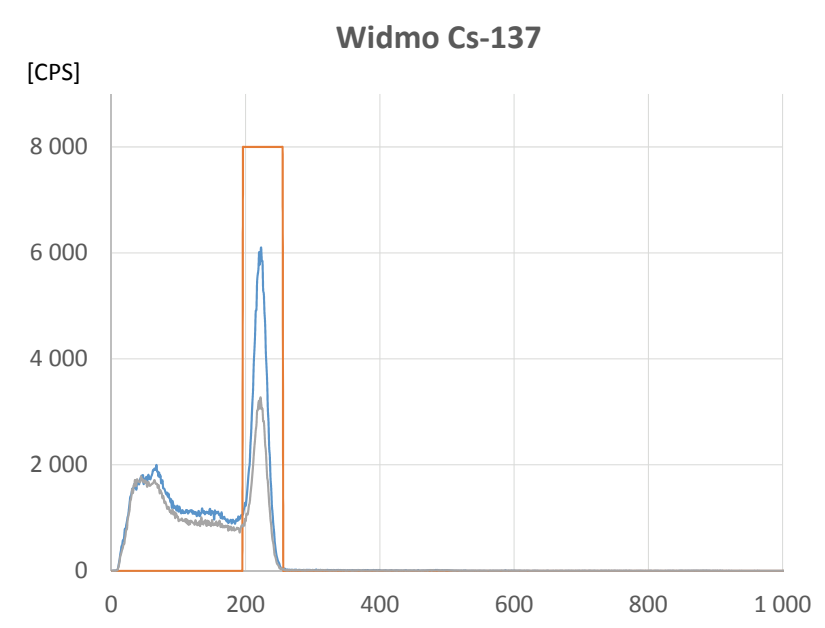

a)

-wzorzec PL —okno -wzorzec AL [channel]

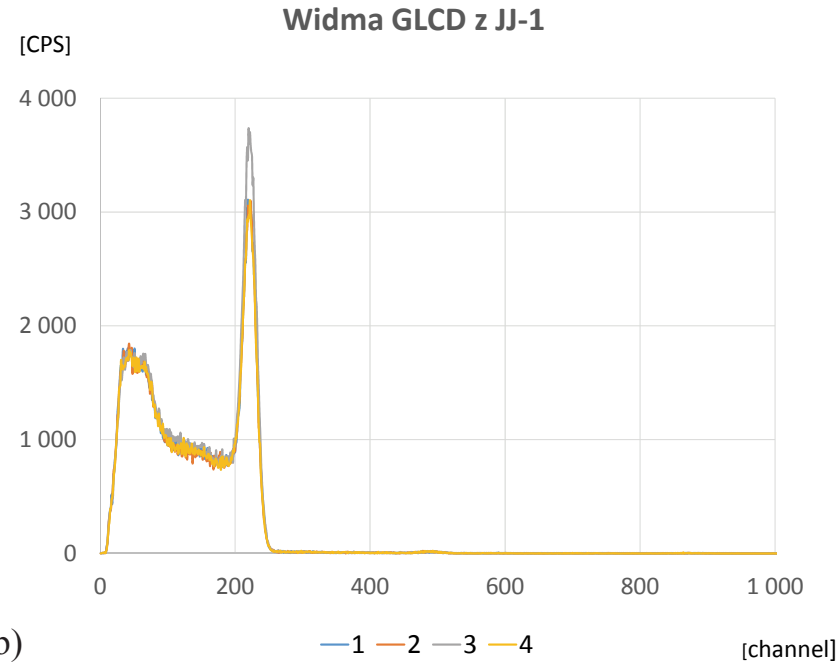

Rys. 5. A) widma z pomiarów wzorców z zaznaczonym oknem wykorzystywanym do szacowania gęstości dla skał o podwyższonej naturalnej promieniotwórczości gamma; B) cztery przykładowe widma z pomiarów gęstościowych rdzenia JJ-1. Na osi pionowej zaznaczono liczbę zliczeń detektora, na osi poziomej - kanały, w których nastąpiły zliczenia

Przeprowadzone badanie wykazało, że zliczenia detektora dla K, U i Th nawet w przypadku rdzeni o podniesionej naturalnej promieniotwórczości nie mają dużego wpływu na otrzymane wyniki. Na wykresie „Widmo Cs-137” piki pocho-

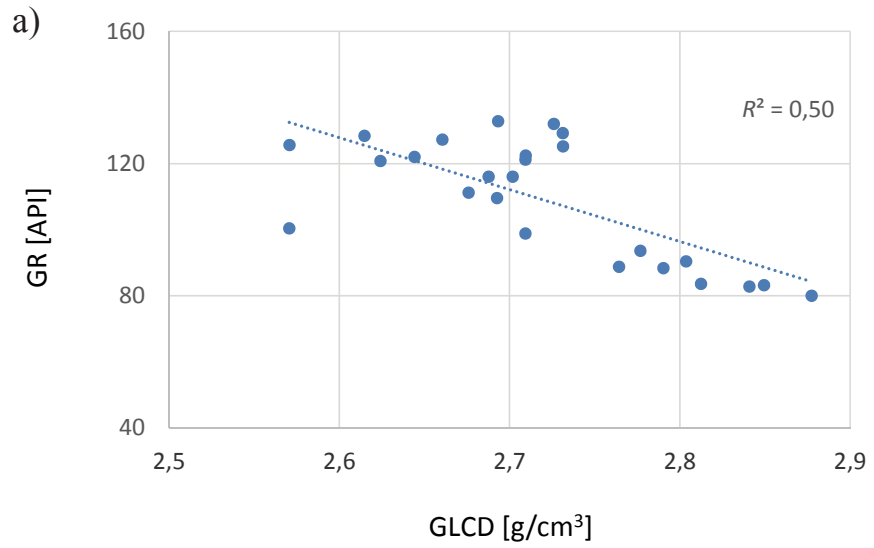

witej intensywności kwantów gamma pochodzącej od pierwiastków promieniotwórczych „total”. Otrzymane wykresy (rysunek 6) pokazują, że wpływ pierwiastków promieniotwórczych K, U, Th na wyniki jest niewielki.

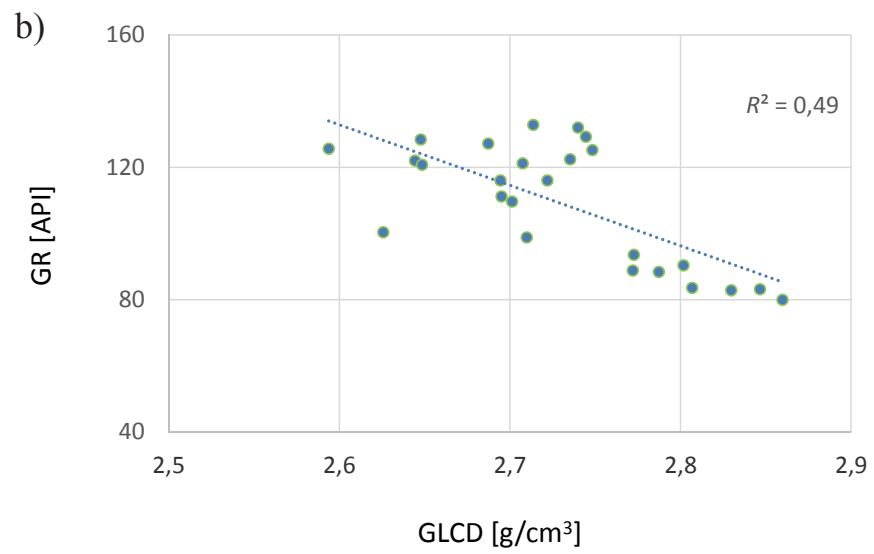

Rys. 6. Korelacja wyników pomiarów gęstości GLCD z wynikami profilowania gamma, czyli pomiaru całkowitej naturalnej promieniotwórczości gamma „total”; a) zestawienie z gęstością objętościową otrzymaną z całego widma; b) zestawienie z gęstością objętościową otrzymaną z piku cezowego

dzące od naturalnych pierwiastków występujących w rdzeniu nie są dostrzegalne. Skala logarytmiczna pozwala zauważyć niewielki procent zliczeń pochodzących od omawianych czynników. Aktualnie operacje na widmach zajmują wiele czasu z powodu braku oprogramowania do ich obróbki. W przypadku pomiaru gęstości rdzeni łupkowych o bardzo wysokiej naturalnej promieniotwórczości będzie wymagana analiza widmowa oraz napisanie programu komputerowego, który przeprowadzi operacje na dużej liczbie widm jednocześnie.

W celu sprawdzenia wpływu promieniotwórczości naturalnej na mierzoną gęstość wykonano korelację pomiędzy gęstością objętościową GLCD a wynikiem pomiaru całko-

\section{Otwór P-4}

Otwór P-4 zawiera rdzenie wiertnicze pochodzące z piaskowcowych formacji czerwonego spągowca. Cechują się one niskim stopniem spękania, niską promieniotwórczością naturalną oraz posiadają odcinek o znacznej zmienności gęstości, co pozwala na wykonanie dokładniejszej analizy właściwości. Jedyną wadą analizowanego rdzenia, z punktu widzenia techniki pomiarowej, jest jego zmienna średnica (rysunek 7A). Niestety średnica ma bardzo duży wpływ zarówno na pomiary gamma, jak i pomiary gęstościowe gamma-gamma. Wyniki rentgenowskiej tomografii komputerowej pozwalają na łatwe wyeliminowanie tego problemu. 
Rezultaty badań gęstościowych (CTCD, GLCD, RHOB, laboratoryjne) oraz stanu i struktury rdzeni (rozwinięcie obra$\mathrm{zu}$, średnica rdzenia) przedstawiono wraz z korelacjami poszczególnych krzywych na rysunku 7.

Pierwsza część badanego rdzenia z otworu P-4 (rysunek 7A) ma trzy metry długości, z czego dwa metry cechują się znacznymi odstępstwami od średnicy nominalnej- $65 \mathrm{~mm}$, w niektórych punktach $56 \mathrm{~mm}$. Wpływ zmian średnicy na wyniki gęstości GLCD jest bardzo wysoki. Zestawienie z pomiarami geofizyki otworowej oraz badaniami laboratoryjnymi pokazuje odstępstwa GLCD od oczekiwanych wartości. Rdzeń na głębokości 3002 $\div 3003 \mathrm{~m}$ ma średnicę nominalną oraz cechuje się niską ilością spękań. W tym odcinku obserwuje się wyższą dokładność dopasowania do wyników pozostałych badań. Zmiany średnicy nie mają większego wpływu na pomiary CT, należy jedynie zaznaczyć odpowiedni obszar przekroju rdzenia, który ma zostać wzięty do uśredniania wyniku HU. W praktyce oznacza to zmniejszenie promienia w programie obliczeniowym dla analizowanego odcinka (pozbawienie obszaru branego do obliczeń wpływu powietrza, zaniżającego gęstość). Materiał skalny w analizowanym interwale cechuje się bardzo podobnymi wartościami gęstości. Korelacje pomiędzy GLCD a RHOB i CTCD są bardzo niskie.

Druga część siedmiometrowego interwału z otworu P-4 została przedstawiona na rysunku $7 \mathrm{~B}$. Ten odcinek charak- teryzuje się niewielkimi odstępstwami średnicy nominalnej oraz zmiennością gęstości, co widoczne jest również na zapisie sondy otworowej. Wytypowany odcinek rdzenia ma stosunkowo dobrą kondycję fizyczną. Pustki powstałe w wyniku badań laboratoryjnych starano się omijać podczas pomiarów lub uśrednić zaniżony wynik. Zestawienie krzywej GLCD zarówno z wynikiem profilowania otworowego RHOB, jak i pomiarami CTCD dało zadowalające korelacje ( $R^{2}$ powyżej 0,6 ). W danym odcinku wykonano wiele badań gęstości objętościowej w laboratorium, co umożliwiło również obliczenie współczynnika determinacji $R^{2}=0,49$.

Przeprowadzone analizy na rdzeniach z otworu P-4 pozwoliły zauważyć znaczny wpływ zmian średnicy rdzeni na pomiary aparaturą gamma logger. W przypadku złego dostosowania parametrów przestrzeni branej pod uwagę podczas wyznaczania krzywej HU możliwe jest otrzymanie nieprawdziwych wartości gęstości radiologicznej. Należy się upewnić, czy obszar obrazu rdzenia nie jest wypełniony pustkami. Pomiar średnicy rdzenia ma duże znaczenie i pozwala ocenić, które odcinki wymagają wprowadzenia poprawek lub odrzucenia.

\section{Otwór Pt-1}

W otworze Pt-1 badania wykonano na rdzeniach pobranych z formacji anhydrytowo-węglanowych, które cechuje

a)

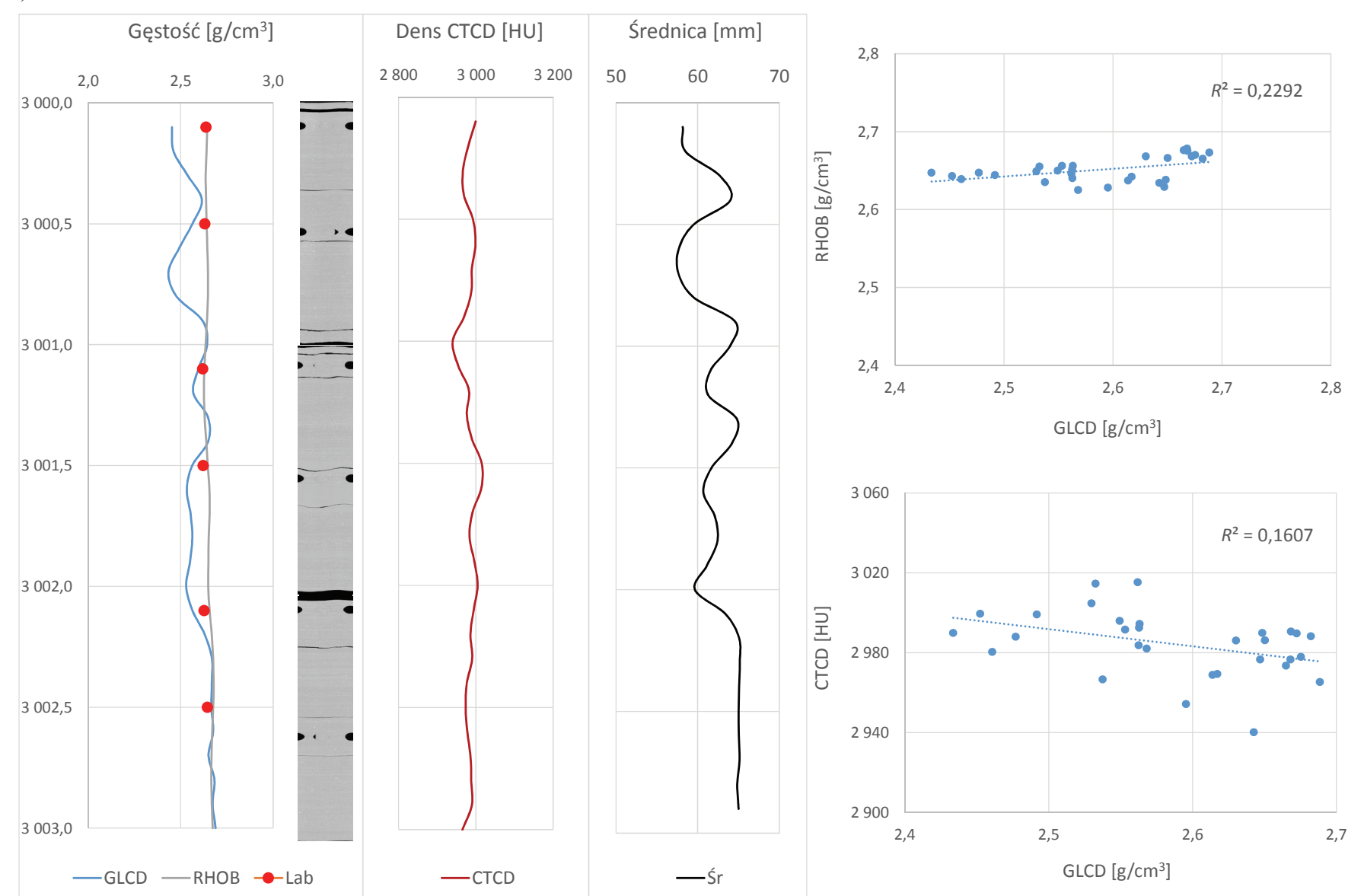


b)

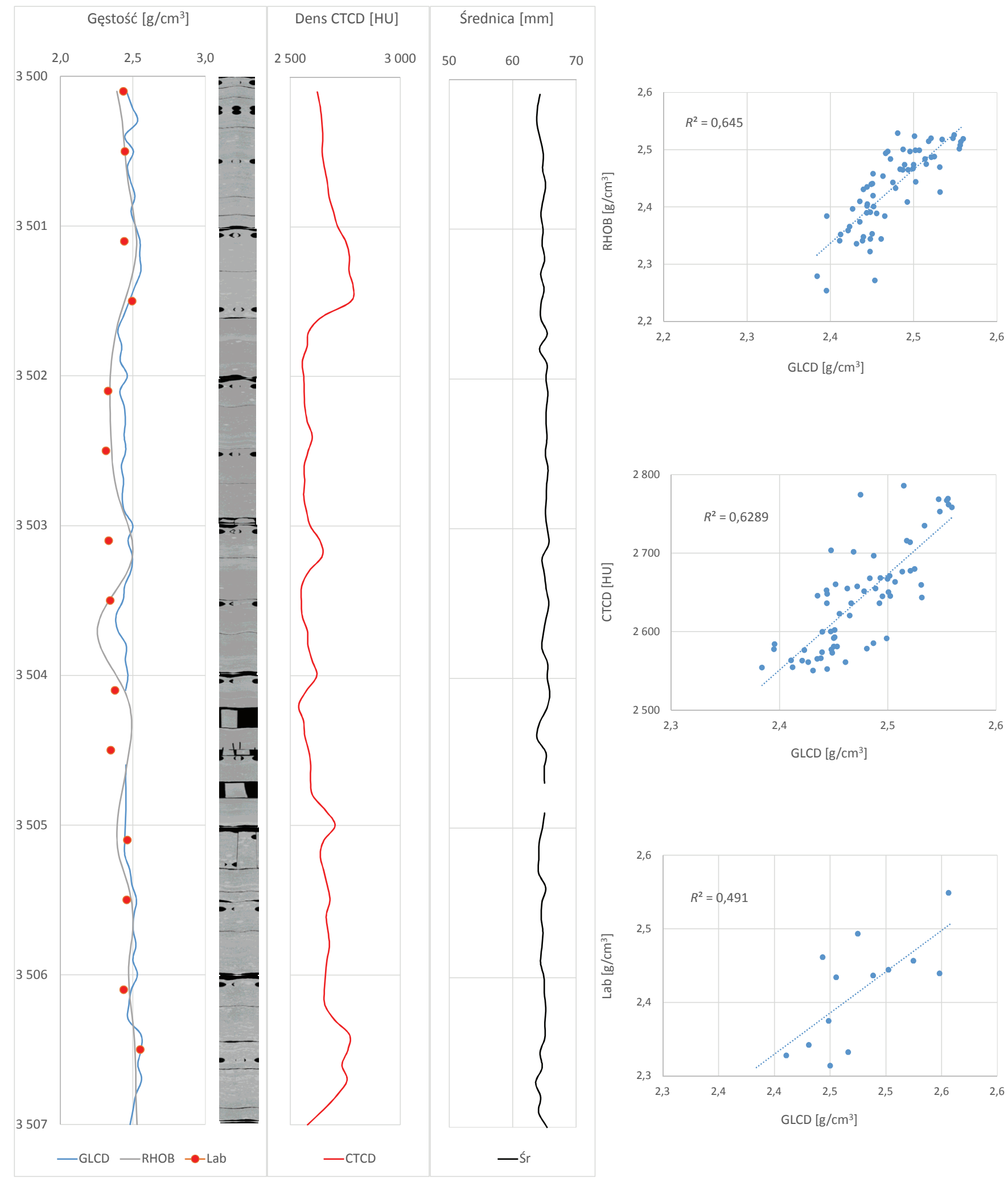

Rys. 7. Zestawienie profilowań CTCD/GLCD z krzywą geofizyki wiertniczej RHOB, wynikami badań laboratoryjnych (Lab) oraz obrazem struktury rdzenia i krzywą zmian średnicy; a) interwał o zmiennej średnicy; b) interwał o stałej średnicy. Do profilowań załączono korelacje RHOB-GLCD, CTCD-GLCD, Lab-GLCD. Głębokości rdzeni zostały zafałszowane

wyjątkowo niska naturalna promieniotwórczość. Rdzenie miały jednakową średnicę i dlatego pominięto pomiar tego parametru. Długość badanego interwału wynosi 6 metrów, wykonano na nim dodatkowe analizy laboratoryjne (dwa punkty) w celu porównania wyników z ciągłymi pomiarami na rdzeniu. 


\section{NAFTA-GAZ}

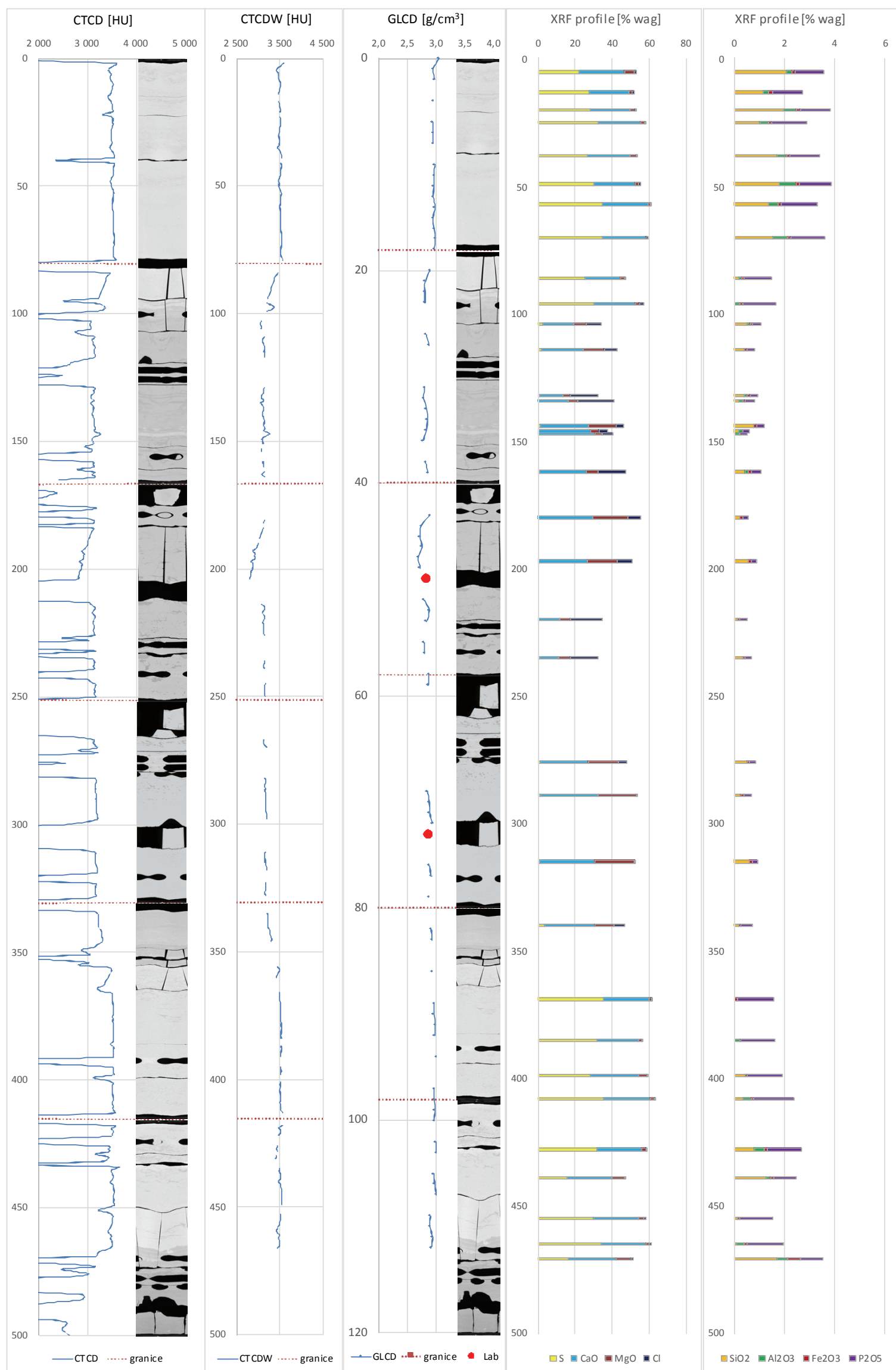

Rys. 8. Wyniki badań rdzenia anhydrytowo-węglanowego. CTCD - gęstość wyrażona w jednostkach HU, CTCDW - krzywa CTCD pozbawiona wpływu pustek, GLCD - krzywa gęstości objętościowej pozbawiona wpływu pustek, Lab - wyniki laboratoryjnych badań gęstości objętościowej, XRF profile - skład chemiczny określony przenośną aparaturą EDXRF. Dodatkowo na wykresach przedstawiono obrazy 2D oraz granice rdzeni 
Dostarczony materiał był po procedurze poboru próbek na badania laboratoryjne, przez co w profilu jest wiele pustek, które zostały odseparowane od wyników otrzymanych z pełnej objętości rdzenia. W przypadku tego otworu z powodu dużej ilości pustek podniesiono dokładność realizacji obu metod. Dla badań CTCD krok pomiarowy wynosił $1,2 \mathrm{~cm}$, natomiast dla GLCD $-5 \mathrm{~cm}$. Różny krok wymagał zestawienia wyników na dwóch osobnych skalach wraz z zaznaczonymi granicami rdzeni (rysunek 8).

Rysunek 8 przedstawia wyniki pomiarów rdzenia, cechującego się zmiennością gęstości na odcinku 3 metrów (odczyt głębokości ze skali dla pomiarów CT): od punktu pomiarowego 0 do 90 średnia gęstość wynosi $3510 \mathrm{HU}-2,96 \mathrm{~g} / \mathrm{cm}^{3}$; od punktu 81 do 350 średnia gęstość spada do $3135 \mathrm{HU}-2,83 \mathrm{~g} / \mathrm{cm}^{3}$; od punktu 351 do 466 średnia gęstość podnosi się do $3505 \mathrm{HU}$ $-2,96 \mathrm{~g} / \mathrm{cm}^{3}$. Na końcu rdzenia znów następuje spadek gęstości skały, co widać na ciemniejszym kolorze rozwiniętego obrazu. Wynik ten nie był brany do korelacji z powodu dużych braków materiału, mocno wpływających na rezultaty przeprowadzonych badań. Na rdzeniu wykonano badania laboratoryjne w dwóch punktach umieszczonych w warstwie o obniżonej gęstości. Średnia gęstość objętościowa wyznaczona na próbkach to $2,84 \mathrm{~g} / \mathrm{cm}^{3}$. Na podstawie pomiarów samej gęstości można ocenić, jakiego typu skały wchodzą w skład mierzonego interwału. Warstwy o podniesionej gęstości są zbudowane z anhydrytu, którego gęstość wynosi $2,96 \div 2,98 \mathrm{~g} / \mathrm{cm}^{3}$, natomiast warstwy o obniżonej gęstości to dolomit, mający gęstość $2,8 \div 2,9 \mathrm{~g} / \mathrm{cm}^{3}$. W celu potwierdzenia zmienności litologicznej i dokładnego jej opisu wykonano dodatkowo serie pomiarów geochemicznych przy wykorzystaniu spektrometru XRF [3, 13]. Profil podzielono na dwie części, wyznaczono pierwiastki główne dla danej formacji oraz pierwiastki o mniejszej koncentracji. Badania wykazały zgodność gęstości dla danych typów litolo- gicznych skał. W warstwach o podniesionej gęstości stwierdzono głównie siarkę oraz wapń (anhydryt $-\mathrm{CaSO}_{4}$ ). Wystąpiły także domieszki kwarcu, minerałów ilastych oraz fosforu (suma masy tych minerałów była poniżej $4 \%$ wag.). Warstwy o obniżonej gęstości zawierają głównie wapń oraz magnez (dolomit - $\mathrm{CaMg}\left[\mathrm{CO}_{3}\right]_{2}$ ), suma pierwiastków współwystępujących to około $1 \%$ wag. W formacjach dolomitowych obecna jest znaczna ilość chloru, co dodatkowo daje informację na temat dużego zasolenia wód złożowych i wtórnej krystalizacji na powierzchni wydobytego rdzenia.

Krzywą CTCD uśredniono na podstawie wartości z trzech najbliższych punktów pomiarowych w celu otrzymania podobnych rozdzielczości obu metod. Wstępne przetwarzanie danych polegało na usunięciu pustek, sztucznie obniżających gęstość, oraz manualnym dopasowaniu głębokościowym punktów pomiarowych CTCD z GLCD, co pozwoliło na otrzymanie zadowalających korelacji o współczynniku determinacji $R^{2}=0,69$. Spękane części rdzenia oraz te zawierające stylolity również zostały uwzględnione w korelacji (rysunek 9).

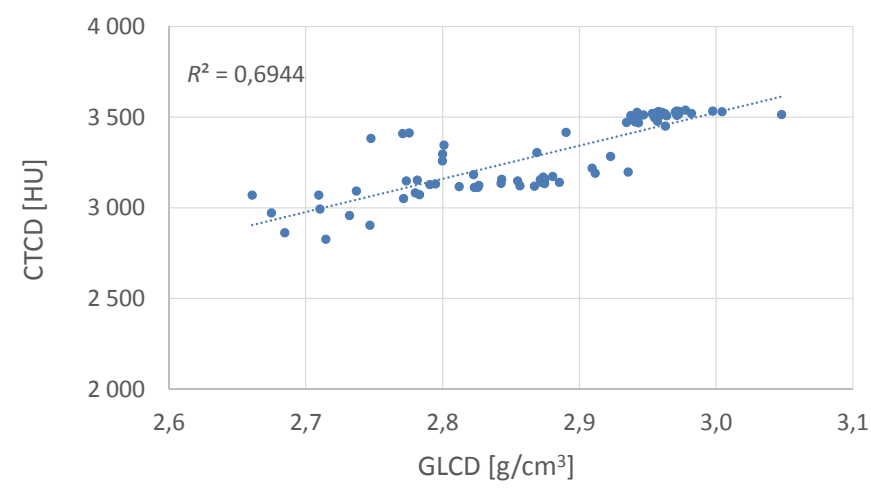

Rys. 9. Wykres korelacyjny wyników pomiarów gęstości CTCD/GLCD otrzymanych podczas badań rdzenia z otworu Pt-1

\section{Podsumowanie i wnioski}

Do realizacji pracy wykorzystano nieinwazyjne aparaty serwisowe, umożliwiające otrzymanie wysokorozdzielczych wykresów gęstości objętościowej, gęstości wyrażonej w jednostkach HU, składu chemicznego oraz obrazów tomograficznych i pomiaru naturalnej promieniotwórczości gamma. Uzyskane wyniki były pozbawione wpływu otworu wiertniczego. Pomiarów dokonano z zastosowaniem metod rentgenowskiej tomografii komputerowej, spektrometrii gamma-gamma oraz aparatury EDXRF. Dodatkowo, w celu porównania rezultatów oraz sprawdzenia ich dokładności, wykorzystano wyniki badań laboratoryjnych oraz profilowania gęstościowe geofizyki otworowej. Badania przeprowadzono na rdzeniach wiertniczych o zmiennej litologii i właściwościach geomechanicznych (systemy spękań) pochodzących z czterech otworów.
Tomografia komputerowa pozwoliła uzyskać dane do utworzenia obrazu 2D, co umożliwiło ocenę wpływu pustek na otrzymane wyniki oraz zobrazowanie szczegółów budowy formacji skalnych, które w przypadku pomiarów otworowych nie są możliwe do zinterpretowania. Obrazy zostały przetworzone na profil 1D gęstości CTCD do szacunkowej oceny zmian gęstości objętościowej. Badania GLCD są obarczone wpływami zmian średnicy rdzenia, spękań oraz pustek. W przypadku pomiarów CTCD również występują podobne problemy, ale edycja wysokorozdzielczego obrazu umożliwia łatwe i dokładne ich wyeliminowanie. Wyniki otrzymane podczas badań GLCD i CTCD wykazały zadowalającą zgodność w interwałach pozbawionych ubytków. Wyniki uzyskane na rdzeniach mocno spękanych lub o zmiennej średnicy były trud- 
ne do interpretacji i ich korelacja wykazała niski współczynnik $R^{2}$. W przypadku pomiarów GLCD rdzeń powinien mieć jednakową średnicę oraz być w dobrym stanie.

Badania na rdzeniach dają wiele informacji o całości pobranego materiału. Rzetelna analiza może być przeprowadzona przed poborem prób na badania laboratoryjne, kiedy rdzeń jest w całości. Zaproponowane metody pozwalają zarejestrować anomalie pominięte przez profilowania otworo- we o mniejszej rozdzielczości lub w wyniku zbyt rzadko pobranych prób do badań laboratoryjnych. Rozwój badań serwisowych pozwala uniknąć wielu pomyłek oraz znacznie poszerzyć wiedzę na temat analizowanych formacji o zróżnicowanej litologii i strukturze badanych skał. W przypadku każdych badań i inwestycji należy dobrać odpowiedni zestaw pomiarów serwisowych w zależności od potrzeb oraz możliwości finansowych danego projektu.

Prosimy cytować jako: Nafta-Gaz 2017, nr 8, s. 571-582, DOI: 10.18668/NG.2017.08.04

Artykuł nadesłano do Redakcji 14.12.2016 r. Zatwierdzono do druku 25.05.2017 r.

Artykuł powstał na podstawie pracy statutowej pt.: Zastosowanie ciagłego pomiaru absorpcji promieniowania elektromagnetycznego w badaniu rdzeni wiertniczych - praca INiG - PIB na zlecenie MNiSW; nr zlecenia: 0003/SW/16/01, nr archiwalny: DK-4100-3/16.

\section{Literatura}

[1] Abel R.L., Laurini C.R., Richter M.: A palaeobiologist's guide to 'virtual'micro-CT preparation. Palaeontologia Electronica 2012, vol. 15, nr 2, art. 6T, $17 \mathrm{~s}$.

[2] Ashi J.: Computed tomography scan image analysis of sediments. Proceedings of the Ocean Drilling Program, Scientific Results 1997, vol. 156, s. 151-158.

[3] Bosco G.L.: Development and application of portable, handheld X-ray fluorescence spectrometers. James L. Waters Symposium 2012 Report. Trends in Analytical Chemistry 2013, vol. 45 , s. $121-134$

[4] Brown E.T.: Rock Characterization Testing and Monitoring - ISRM Suggested Methods. Pergamon Press, 1981, 211 s.

[5] Chan A.M.C., Banerjee S.: Design aspects of gamma densitometers for void fraction measurements in small scale two-phase flows. Nuclear Instruments and Methods in Physics Research 1981, vol. 190, nr 1, s. 135-148.

[6] Freifeld B.M., Kneafsey T.J., Tomutsa L., Pruess J.: Development of a portable X-Ray computed tomographic imaging system for drill site investigation of recovered core. Report Number: LBNL-52088 Abs, 2003.

[7] Jussiani E.I., Appoloni C.R.: Effective atomic number and density determination of rocks by X-ray microtomography. Micron 2015, vol. 70, s. 1-6.

[8] Lisieski W.: Praktyczna spektrometria promieniowania gamma $w$ badaniach technicznych. Nowa Technika, zeszyt 70, Wydawnictwa Naukowo-Techniczne, Warszawa 1967.

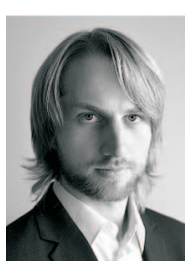

Mgr inż. Rafał SKUPIO

Asystent w Zakładzie Geofizyki Wiertniczej. Instytut Nafty i Gazu - Państwowy Instytut Badawczy ul. Lubicz 25 A

31-503 Kraków

E-mail: rafal.skupio@inig.pl
[9] Nakashima Y., Komatsubara J.: Seismically induced softsediment deformation structures revealed by $X$-ray computed tomography of boring cores. Tectonophysics 2016, vol. 683, s. $138-147$.

[10] Park H.-S., Chung C.-H.: Design and application of a singlebeam gamma densitometer for void fraction measurement in a small diameter stainless steel pipe in a critical flow condition. Nuclear Engineering and Technology 2007, vol. 39, nr 4, s. $349-358$

[11] Ross P.-S., Bourke A.: High-resolution gamma ray attenuation density measurements on mining exploration drill cores, including cut cores. Journal of Applied Geophysics 2017, vol. 136, s. 262-268.

[12] Schlieper G.: Principles of gamma ray densitometry. Metal Powder Report 2000, vol. 55, s. 20-23.

[13] Skupio R.: Wykorzystanie przenośnego spektrometru XRF do pomiarów składu chemicznego skat. Nafta-Gaz 2014, nr 11, s. 771-777.

[14] Skupio R., Dohnalik M.: Improvement spectrometric gamma measurements on shale cores with the use of the BGO scintillation detector. Nafta-Gaz 2015, nr 11, s. 847-855. DOI: 10.18668/NG2015.11.06.

[15] Strona internetowa http://www.medipment.pl (dostęp: wrzesień 2016).

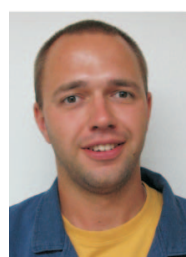

Dr inż. Marek DOHNALIK

Kierownik Zakładu Geofizyki Wiertniczej.

Instytut Nafty i Gazu - Państwowy Instytut Badawczy ul. Lubicz 25 A

31-503 Kraków

E-mail: marek.dohnalik@inig.pl 